DOI https://doi.org/10.30525/978-9934-26-114-5-9

\title{
МОТИВАЦІЯ ЯК КОРЕЛЯТ РОЗВИТКУ ПСИХОЛІНГВІСТИЧНОЇ КОМПЕТЕНТНОСТІ У СТУДЕНТІВ
}

\author{
Шукалова О. С.
}

кандидат психологічних наук, дочент, дочент кафедри педагогіки, психології, початкової освіти та освітнього менеджменту

Комунальний заклад «Харківська гуманітарно-педагогічна академія» Харківської обласної ради

Зайцева О. О.

викладач кафедри педагогіки, психології, початкової освіти та освітнього менеджменту

Комунальний заклад «Харківська гуманітарно-педагогічна академія» Харківської обласної ради м. Харків, Україна

Розвиток психолінгвістичної компетентності як «психолінгвістичного феномена, що дає можливість якісно, уміло та швидко регулювати психолінгвістичі процеси» [7 с. 38 ], дає студенту можливість вміло викладати свої думки та залучати оточуючих прийняти свої ідеї та слідувати за ним. Велику роль в розвитку психолінгвістичної компетентності студентів відіграє мотивація. Наявність такого впливу на успішність студентів вміло формулювати думки, правильно доносити власні ідеї, схиляти людей на свій бік було доведено великою кількістю вчених, однак багато питань пов'язаних з мотивацією у цій області залишаються відкритими.

Вивченням психолінгвістичних процесів займалися такі відомі вчені як В. Белянін [3], В. Глухов [5], О. Лурія [13], Т. Ушакова [17], О. Ахманова [2], Т. Дрідзе [6] тощо. Проблеми мотивації вивчали Дж. Аткінс [19], Д. Макклеланд [19], Х. Хекхаузен [18], А. Маслоу [16], О. Леонтьєв [12], О. Асмолов [1], М. Магомед-Емінов [15], Є. Ільїн [8], Є. Клімов [9], А. Маркова [15] тощо.

Метою даного дослідження було виявлення наявності впливу загальних та професійних мотивів на показники психолінгвістичної компетентності студентів.

Емпіричне дослідження було здійснено за допомогою одинадцяти психодіагностичних методик: «Вміння слухати», «Вміння висловлювати свої думки», «Вміння переконувати інших», «Діагностика особливості на мотивацію до успіху» (Т. Елерс), «Діагностики 
особистості на мотивацію до уникнення невдач» (Т. Елерс), «Афіліації» (А. Мехрабіан), «Мотив влади», «Академічна саморегуляція» (Р. Райан, Д. Коннелл в адаптації М. Яцюка), «Мотиви вибору професії» (С. Груншпун), «Мотивація навчання у ЗВО» (Т. Ільїна), «Професійна мотивація».

В процесі статистичної обробки було здійснено кореляційний аналіз показників психолінгвістичної компетентності («Вміння слухати», «Вміння висловлювати свої думки», «Вміння переконувати інших») та загальних і професійних мотивів (досягнення успіху, уникнення невдачі, причетності, запобігання знехтування, влади, зовнішнього регулювання, інтроектованого регулювання, ідентифікованого регулювання, власного спонукання, вибору престижної професії, вибору матеріальних благ, прагнення творчої роботи, придбання знань, оволодіння професією, отримання диплома, власної праці, соціальної значущості праці, самоствердження у праці, професійної майстерності).

Прямий взаємозв'язок з показником «Вміння слухати» утворили такі загальні та професійні мотиви як досягнення успіху, уникнення невдачі, причетності, запобігання знехтування, влади, ідентифікованого регулювання, власного спонукання, прагнення творчої роботи, придбання знань, оволодіння професією, соціальної значущості праці, професійної майстерності. Отже, у студентів, в яких на першому місті знаходиться бажання досягти успіху в навчанні, бути вагомою частиною соціальної групи, дістати мети за будь яких умов, отримувати освіту не заради диплома та похвали, а заради знань і професійної майстерності, більше розвинене вміння виділяти 3 отриманої інформації ту, яка наповнена змістом і потрібна йому найбільше на даний момент.

Статистично значущій прямий взаємозв'язок із показником «Вміння висловлювати свої думки» встановили оцінки мотивів досягнення успіху, причетності, влади, ідентифікованого регулювання, власного спонукання, прагнення творчої роботи, придбання знань, оволодіння професією, соціальної значущості праці, професійної майстерності. Таким чином, вміння донести власні думки до оточуючих людей, притаманне студентам вмотивованим безпосередньо власними бажаннями отримувати знання, бути причетними до соціальних груп, творчо розвиватися і працювати на благо суспільству.

Прямий кореляційний зв'язок утворили показник психолінгвістичної компетентності «Вміння переконувати інших» та загальні і професійні мотиви досягнення успіху, причетності, влади, ідентифікованого регулювання, власного спонукання, прагнення творчої роботи, придбання знань, оволодіння професією, соціальної значущості праці, 40 
професійної майстерності. Отже, студенти, які бажають досягти успіху в навчанні, бути вагомою частиною соціальної групи, для яких обрана професія $\epsilon$ не тільки шляхом самоствердження, фінансового благополуччя та визнання, а засобом розвитку своєї спеціальності та суспільства взагалі, вміють правильно донести власні думки до оточуючих їх людей, переконати у своїй правоті і грамотності власних ідей.

Аналіз отриманих даних дозволяє дійти висновку, що мотивація $\epsilon$ вагомим чинником розвитку психолінгвістичної компетентності.

\section{Література:}

1. Асмолов А. Г. Психология личности : Учебник. Москва : МГУ, $1990.367 \mathrm{c}$.

2. Ахманова О. С. О психолингвистике. Москва, 1957

3. Белянин В. П. Введение в психолингвистику. Москва : ЧеРо, 1999. $128 \mathrm{c}$.

4. Выготский Л. С. Мышление и речь. Москва : Лабиринт, 2001. $368 \mathrm{c}$.

5. Глухов В. П. Основы психолингвистики Москва : АСТ, Астрель, 2008. $352 \mathrm{c}$.

6. Дридзе Т. М. Текстовая деятельность в структуре социальной комуникации. Проблемы семисоциопсихологии. Москва : Высшая школа, 1980

7. Зайцева О. О. Мотиваційні чинники розвитку метакогнітивної активності у структурі академічної саморегуляції студентів: дис. 053. Харків, 2020. 228c.

8. Ильин Е. П. Мотивация и мотивы : учебное пособие. СанктПетербург : Питер, 2002. 512 с.

9. Климов Е. А. Как выбирать профессию. Москва : Просвещение, $1991.158 \mathrm{c}$

10. Леонтьев А. А. Основы психолингвистики. Москва : Смысл, 2003. $287 \mathrm{c}$.

11. Леонтьев А. А. Психолингвистические единицы и порождение речевого высказывания. Москва : Наука, 1969. 307 с.

12. Леонтьев А. Н. Потребности, мотивы и эмоции. Москва : Изд-во. Моск. ун-та, 1971. с. 13-39.

13. Лурия А. Р. Основные проблемы нейролингвистики. Москва : МГУ, 1975.

14. Магомед-Эминов М. Ш., Васильев И.А. Мотивация и контроль за действием Москва : МГУ, 1991. 144 с.

15. Маркова А. К., Матис Т. А., Орлов Б. А. Формирование мотивации учения. Москва : Просвещение, 1990. 192 с. 
16. Маслоу А. Г. Мотивация и личность. Санкт-Петербург : Евразия, 1999. $478 \mathrm{c.}$

17. Ушакова Т.Н. Психолингвистика : учебник для вузов. Москва : Пер Сэ, 2006. 415 c.

18. Хекхаузен Х. Психология мотивации достижения : учебн. пособ. Санкт-Петербург : Речь, 2001. 240 с

19. McClelland D.C., Atkinson J.W. Methods of measuring human. Motives in fantasy, action and society. Princeton (NJ) : Van Nostrand, 1958. pp. 7-42. 